\title{
PENERAPAN SUPERVISI AKADEMIK DALAM UPAYA PENINGKATAN MOTIVASIGURU DALAM MENYUSUN PERANGKAT PERSIAPAN PEMBELAJARAN
}

\author{
Sylvia Yunita \\ Email: Sylviayunita09@gmail.com
}

\begin{abstract}
Abstrak
Supervisi adalah pengamantan secara langsung dan berkala oleh atasan terhadap pekerjanya yang dilakukan bawahan, apabila ditemukan masalah segera diberikan bantuan yang bersifat langsung guna mengatasinya. Sasaran supervisi akademik adalah dosen atau instruktur dalam proses pembelajaran, yang terdiri dar materi pokok dalam proses pembelajaran mengelola proses pembelajaran demi pencapaian tujuan pembelajaran. Dengan demikian kegiatan supervisi adalah kegiatan yang positif dan mulia, yaitu membantu guru untuk meningkatkan proses dan hasil belajar, maka banyak pakar yang memberikan batasan supervisi sebagai bantuan kepada staf untuk mengembangkan situasi pengajaran yang lebih baik.
\end{abstract}

Kata Kunci: supervisi, pembelajaran, guru

\section{A. LATAR BELAKANG}

Pendidikan adalah upaya yang dilakukan secara sadar untuk memperbaiki sumber daya manusia. Melalui pendidikan yang baik diharapkan terciptanya sumber daya manusia yang baik, salah satu upaya yang dapat dilakukan oleh pemerintah melalui pendidikan adalah dengan memperbaiki proses pembelajaran di sekolah. Karena itu guru memiliki peranan penting dalam hal ini. Baik dalam proses pembelajaran maupun peningkatan kualitas sumber daya secara tidak langsung (Departemen Pendidikan Naisonal, 2002).

Penyelenggaran pendidikan bertujuan untuk membantu anak-anak dan peserta didik dalam mencapai kedewasaannya, sehingga mereka mampu menyesuaikan diri dimasyarakat sekitar. Sesuai dengan Undang-Undang Republik Indonesia Nomor 20 Tahun 2003 Tentang Sistem Pendidikan Nasional, Pasal 3 pendidikan berfungsi dan bertujuan sebagai berikut:

Yaitu pendidikan nasional berfungsi mengembangkan kemempuan dan membentuk watak serta peradaban dari bangsa yang memiliki martabat dalam rangka mencerdaskan kehidupan bangsa dan negara, dan bertujuan untuk mengembangkan potensi yang dimiliki pesrta didik agar kelak menjadi manusia yang bermutu dan bertaqwa kepada tuhan yang maha esa, berakhlak mulia, sehat, berilmu, memiliki kecakapan, serta kreatif dan menjadi wrga negara yang demokratis serta bertanggung jawab.

Disini ada 3 sebab yang muncul sebagai alasan, pertama guru beum memiliki kecakapan atau keterampilan menyusun perangkat persiapan pembelajaran.kedua, guru enggan untuk menyusun perangkat persiapan pembelajaran, ketiga guru tidak punya cukup waktu untuk membuatnya. Berdasarkan latar belakang inilah, permasalahan penelitian ini solusinya adalah pertama, mengadakan workshop guru untuk menyusun perangkat persispan pembelajaran. Selanjutnya memberika reward dan penghargaan 
kepada guru yang telah menyusun perangkat pembelajaran, selanjutnay memberikan sanksi pada guru yang tidak memnyusun perangkat pembelajaran.

\section{B. PEMBAHASAN}

Guru merupakan tenaga profesional yang bertugas merencanakan dan melaksanakan proses pembelajaran, menilai hasil pembelajaran serta melakukan pembimbingan kepada peserta didik. Yang secara konseptual supervisi akademik seorang guru ialah serangkaian kegiatan dalam membantu guru mengembangkan kemampuannya dalam mengelola proses pembelajaran demi pencapaian tujuan dari pemebeljaran (Mulyasa, E, 2007). Kualitas pembelajaran di Indonesia diindikasikan belum memenuhi kualitas yang diharapkan. Hal ini, berdampak pada prestasi belajar siswa yang belum menggembirakan terutama dibandingkan prestas belajar siswa di negara lainnya. Supervisi pendidikan memegang peranan penting dalam meningkatkan kualitas pembelajaran guru yang pada akhirnya menghasilkan prestasi belajar siswa yang tinggi (Sabandi, A, 2013).

Kegiatan supervisi merupakan pemberian layanan dan bantuan untuk meningkatkan kualitas mengajar guru dikelas dengan tujuan untuk meningkatkan kualitas belajar siswa yang dimulai dari perencanaan pembelajaran, pelaksanaan kegiatan pebelajaran, mengevaluasi kegiatn pembelajran. Melalui supervisi akademik kepala sekolah mampu menampung berbagai masalah yang dihadapi oleh guru dalam proses pembelajaran dan menemukan pemecahan masalahnya (Sahertian, A, 2000). Menurut (Supandi, 1996). Penelitian ini dilaksanakan melalui penggunaan desain penelitian tindakan yang dirancang melalui 3 siklus. Teknik yang digunakan dalam penelitian ini adalah sebagai berikut :

1. Teknik pengumpulan data, dimana teknik dan pengumpulan data yang digunakan disini ialah teknik tes dan non tes, namun untuk memudahkan teknik yang digunakan hanyalah teknik tes.

2. Jenis data yang digunakan adalah data kualitatif dan data kuantitatif.

3. Teknik dan pengambilan serta pengumpulan data dilakukan dengan cara berikut:a. Metode pemberian tugas atau tes, b. Metode angket, c. Metode dokumentasi.

Berdasarkan data hasil tindakan dari siklus ke siklus, terdapat ada perubahan dan perkwmbangan dari siklus satu kesiklus dua dilihat dari diagaram dan dari siklus 2 ke siklus 3. Bila pada siklus 1, jumlah guru yang menyerahkan dokumentasi silabus ada 4 orang atau 33,33\%, maka pada siklus 2, jumlah guru yang sudah menyerahkan dokumentasi bertambah 2 orang sehingga menjadi 6 orang guru atau 50\%. Selanjutnya siklus 3 jumlah guru yang menyerahkan menjadi 10 orang atau $83,3 \%$.

Selanjutnya dengan demikian tugas kepala sekolah adalah sebagai supervisor, yiatu memmbangkitkan komitmen guru, dan ketika komitmennya telah tumbuh, maka tugas kedua, adalah membimbingnya yaitu mengajarkan bagaimana cara melaksanakananya.Dengan demikian upaya dalam meningkatkan kinerja guru berkisar pada masalah bagaimana komitmen dan kompetensi, keduannya sangat ditentukan oleh suasana hati dan perasaan seseorang (Titik, R 2007).

\section{SIMPULAN DAN SARAN}

\section{Simpulan}

a. Profesional guru adalah tugas mulia, yaitu dalah mencerdaskan kehidupan bangsa, yang mestinya dilakukan dengan niat mulia dan dengan kompetensi yang sesuai dengan standar.

b. Adapun kasus tentang rendahnya kinerja guru, pada dasarnya terkait langsung dengan kualitas komitmen dan komptensi tersebut. 


\section{Saran}

Harapan kepada dinas penidikan baik yang ada ditingkat provinsi maupun daerah untuk menyelenggrakan pembinaan kompetensi kepala sekolah dalam berbagai bidang. Kepada kepala sekolah hendaknya dapat berpikir positif terhadap semua kegiatan pelatihan dan aktif melaksanakan tugas-tugasnya.

\section{DAFTAR PUSTAKA}

Departemen Pendidikan Naisonal. 2002. Supervisi Pendidikan. Jakarta: Direktorat Pendidikan Lanjutan Menengah Pertama.

Mulyasa, E. 2007. Menjadi Guru Profesional Menciptakan Pembelajaran Kreatif dan Menyenangkan. Bandung: Remaja Rosda Karya.

Sahertian, A. 2000. Konsep Dasar dan Teknik Supervisi Pendidikan. Jakarta: Rineka Cipta.

Subandi, A. 2013. Supervisi Pendidikan untuk Meningkatkan Profesionalitas Guru Berkelanjutan. Pedagogik: Jurnal Ilmu Pendidikan, 13 (2), 1-9.

Supandi. 1996. Administrasi dan Supervisi Pendidikan. Jakarta: Depertemen Agama Universitas Terbuka.

Titik, R. 2013. Peningkatan Motivasi Guru dalam Penyusunan Perangkat Pembelajaran Melalui Supervisi Akademik. Brebes: (Tidak Dipublikasi). 